\title{
Mock panels as an active teaching methodology in the education of nursing doctors
}

\author{
Bancas simuladas como metodologia ativa de ensino na formação de doutores em enfermagem \\ Juntas simuladas como una metodología activa de enseñanza en la formación de doctores de enfermería
}

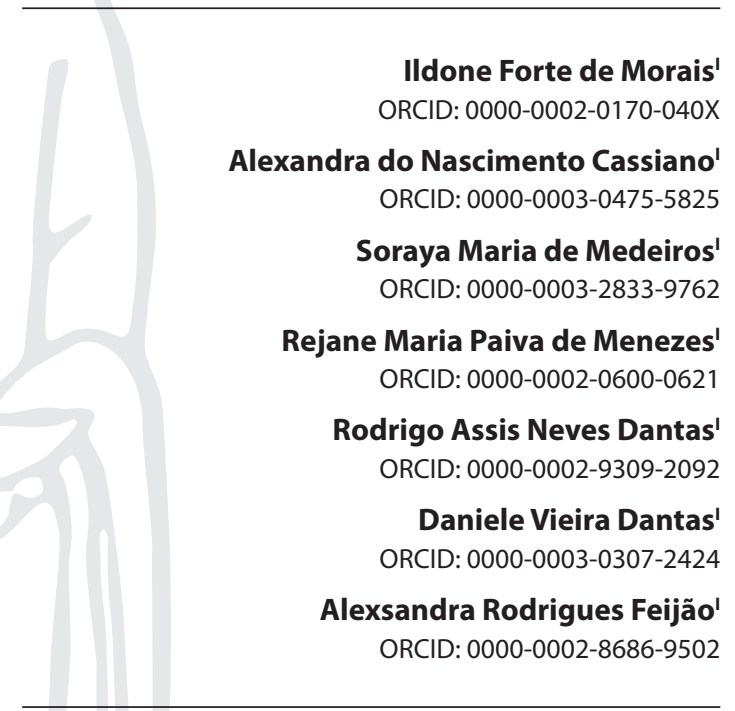

'Universidade Federal do Rio Grande do Norte. Natal, Rio Grande do Norte, Brazil.

How to cite this article:

Morais IF, Cassiano NA, Medeiros SM, Menezes RMP,

Dantas RAN, Dantas DV, et al. Mock panels as an active teaching methodology in the education of nursing doctors. Rev Bras Enferm. 2020;73(6):e20190700. doi: http://dx.doi.org/10.1590/0034-7167-2019-0700

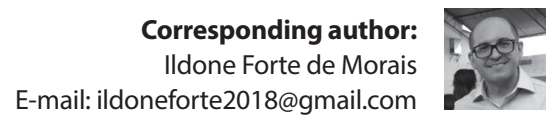

EDITOR IN CHIEF: Antonio José de Almeida Filho ASSOCIATE EDITOR: Ana Fátima Bernardes

\section{ABSTRACT}

Objective: To analyze the experience of doctorate students in the use of mock panels as an active methodology of teaching in Nursing post-graduation. Method: Experience report on the use of mock panels in the discipline Advanced Methods for Researches in Health and Nursing II, offered in the doctorate course of the Nursing Post-graduate Program from the Universidade Federal do Rio Grande do Norte. Results: The mock panels contributed for the doctorate of nurses and enabled students to take on the role of protagonists in the teachinglearning process, through the use of critical thought and student autonomy. Conclusions: This experience made it possible to implement an active teaching-learning methodology in Nursing post-graduation, since this strategy was opposite to the traditional education model. Descriptors: Nursing Education, Postgraduate; Simulation Training; Critical Thinking; Professional Autonomy; Nursing.

\section{RESUMO}

Objetivo: Analisar a experiência de doutorandos na utilização de bancas simuladas como metodologia ativa de ensino na pós-graduação em Enfermagem. Método: Estudo do tipo relato de experiência, sobre a utilização de bancas simuladas na disciplina Métodos Avançados de Pesquisa em Saúde e Enfermagem II, ofertada no curso de doutorado do Programa de Pós-graduação em Enfermagem, da Universidade Federal do Rio Grande do Norte. Resultados: As bancas simuladas contribuíram para a formação de doutores em enfermagem e oportunizaram aos estudantes assumirem o protagonismo do processo ensino-aprendizagem por meio do pensamento crítico e da autonomia discente. Conclusões: A realização dessa experiência possibilitou a implementação de uma metodologia ativa de ensino-aprendizagem na pós-graduação em Enfermagem, porque essa estratégia foi de encontro ao modelo tradicional de educação.

Descritores: Educação de Pós-Graduação em Enfermagem; Simulação; Pensamento Crítico; Autonomia Profissional; Enfermagem.

\section{RESUMEN}

Objetivo: Analizar la experiencia de doctorandos en la utilización de juntas simuladas como metodología activa de enseñanza en el posgrado en Enfermería. Método: Estudio del tipo relato de experiencia, sobre la utilización de juntas simuladas en la disciplina Métodos Avanzados de Investigación en Salud y Enfermería II, ofrecida en el curso de doctorado del Programa de Posgrado en Enfermería, de la Universidad Federal de Rio Grande do Norte. Resultados: Las juntas simuladas contribuyeron para la formación de doctores en enfermería y proporcionó oportunidad a los estudiantes asumieren el protagonismo del proceso enseñanza-aprendizaje por medio del pensamiento crítico y de la autonomía discente. Conclusiones: La realización de esa experiencia posibilitó la implementación de una metodología activa de enseñanza-aprendizaje en el posgrado en Enfermería, porque esa estrategia ha sido opuesta al modelo tradicional de educación.

Descriptores: Enseñanza de Posgrado en Enfermería; Simulación; Pensamiento Crítico; Autonomía Profesional; Enfermería. 


\section{INTRODUCTION}

In Brazil, the evolution of Nursing stricto sensu post-graduation followed policies that made many achievements possible, helping to strengthen and develop innovations in care, management, and teaching and having sociopolitical, scientific, and technological impact on health and on the science of nursing ${ }^{(1)}$. As a result, the education of PhD professionals must seek many strategies capable of qualifying them as future researchers.

Among these, it is important to mention the training of the doctorate student to act as a member of panels to examine scientific initiation papers or course conclusion papers from graduation courses, since this is an essential activity, inherent to the work of a professor and/or researcher. Therefore, the use of mock panels to exercise it aims to contribute for the development of competences, abilities, and domains that can transform the students in professors and researchers capable of producing high-impact science with international relevance ${ }^{(1)}$.

However, the participation of the students in these activities is scarce, perhaps due to the few opportunities offered during the course. That is because the path of teaching in health and in post-graduation has, historically, been based on a teaching model that uses traditional techniques whose objective is only transmitting knowledge.

That reality may lead to gaps and shortcomings in the education of doctors in nursing, since the development of the skills of analyzing, judging, and evaluating scientific works is essential for their professional lives ${ }^{(1)}$. Active methodologies are paths that can strengthen the formation of doctors in Nursing, thus being indicated to overcome said limitations.

Active teaching-learning methodologies, among which is the simulation training, are based on a meaningful theoretical principle: the development of the autonomy of the student. That suggests that contemporary education should assume that the student is capable of self-managing or self-governing their own education process ${ }^{(2)}$. Autonomy is a process of maturing of the beings themselves, which takes place in accordance to many daily life experiences that involve judgments and decision making in dealing with problems ${ }^{(3)}$. When, in the learning process, the student assumes a participative attitude, as opposed to a passive one, they are motivated to think critically and reflexively on their own reality, in addition to mobilizing their knowledge to analyze the resolution of certain situations ${ }^{(4)}$.

Literature reveals that simulation training in mock panels, used as a teaching method, contributes for the learning and the didactic innovation of Nursing students. That improves learning, since the confidence of the students and their ability to communicate improve, and they develop critical thinking, integrating theory and practice ${ }^{(5-7)}$.

The use of this active methodology in post-graduation disciplines, which are the object of study of this article, aims to renew stricto sensu education, as well as to qualify the learning in the process of formation of doctors in Nursing. This strategy is important because Nursing post-graduation teaching is, especially in the doctorate level, expected to develop the autonomy, critical thinking, and creativity of students ${ }^{(8)}$.

Therefore, the use of simulation in the teaching of nursing must be understood as a possibility of previously experiencing, while still in the role of students, situations that may be met in the future context of work. That enables the recognition of these situations and is instrumental for decision making ${ }^{(9)}$.

As a result, this experience report highlights the importance of socializing the strategy of mock panels to qualify the disciplines in the syllabuses of stricto sensu post-graduation courses in Nursing.

\section{OBJECTIVE}

To analyze the experience of doctorate students in the use of mock panels as an active teaching methodology in Nursing post-graduation.

\section{METHODS}

This is an experience report on the use of mock panels as an active teaching methodology in the formation of Nursing doctors. It was developed based on the experiences in the discipline Advanced Methods for Researches in Health and Nursing II. This discipline is offered in the Academic Doctorate course from the Nursing Post-graduation Program in the Universidade Federal do Rio Grande do Norte (PGENF-UFRN).

Experience reports are a modality of work seen as a tool for descriptive researches. It can enable reflections on certain actions or groups of actions that can address experiences in many contexts that are of scientific interest ${ }^{(9)}$. Its aim is to socialize a successful experience and provoke debates on this active teaching methodology used for the education of Nursing doctors.

It was elaborated using oral self-reports of students of the discipline, especially in their final evaluation of it. Official documents made available by the professors of the discipline, such as the general plan (syllabus, goals, objectives, and evaluation), scheduling of classes, and bibliographic references.

The manuscript is based around two axes, which are:"Experience itinerary" and "Analytical report of mock panels". The first one was a result of the need to describe the dynamics of the discipline, while the second one sought to analyze the experience under the light of the scientific literature pertinent to nursing education.

\section{EXPERIENCE ITINERARY}

The discipline Advanced Methods for Researches in Health and Nursing II is mandatory and offered annually for students in the Academic Doctorate in Nursing at UFRN; the course workload is of 45 hours and it is worth 3 credits. According to its syllabus, the discipline aims to:

Offer students the advanced study of logic in hypotheticaldeductive researches to construct knowledge in health and nursing. It includes knowledge on philosophical bases and their relations with study objects in health and nursing, bringing the theoretical and methodological aspects of quantitative study designs closer together. To do so, its objectives are: discussing the use of the quantitative method in health sciences, emphasizing its use in nursing; describing quantitative research designs; and reading, interpreting, and evaluating qualitative scientific studies ${ }^{(10)}$.

The discipline was organized in three units. The first one focused on the concepts - and on discussions about them — of quantitative researches as applied to nursing, involving clinical researches, 
models of quantitative nursing research, and the critical evaluation of nursing researches. The second unit was organized around the presentation of seminaries with the following subjects: cross-sectional and methodological studies, cohort and control-case studies, quasi-experimental and experimental studies, and review studies (integrative and systematic reviews with or without meta-analyses). Finally, the third unit is structured around the presentation of mock panels, based on the subjects discussed in the seminaries.

The mock panels were organized as follows: critical reading and analysis of doctoral theses, selected by the professors of the discipline; followed by the production of a written report evaluating issues seen as relevant, gaps, limitations and/or fragilities in the investigations.

These activities were carried out, initially, through the randomized selection of students who were to present a PhD thesis in Nursing. With that in mind, the other students would produce a report to be read and presented to the class. Their guiding instruments were the recommendations from the quantitative research evaluation protocols, such as the Preferred Reporting Items for Systematic Reviews and Meta-Analyses (PRISMA), the Consolidated Standards of Reporting Trials (CONSORT) and the Strengthening the Reporting of Observational Studies in Epidemiology (STROBE).

After each meeting was done and each thesis presented, three students were randomly chosen to be members of the mock examination panel. After the thesis were exposed, they would offer their considerations based on previously prepared reports. The students who were not selected to be members of the mock panel needed to elaborate and deliver to the professors a report for each thesis discussed.

After the presentation and the reports were concluded, the professors responsible for the discipline would offer feedback, evaluating the performance of both the student responsible for presenting the thesis and of the students who formed the mock panel. At this point, the professors highlighted positive aspects and limitations, in addition to offering guidance with regards to possible approaches that the students could adopt in similar situations.

\section{ANALYTICAL REPORT OF MOCK PANELS: THE REFLEC- TIONS OF THE STUDENTS}

At first, this process was riddled with expectations of insecurity from the students. Many had qualitative methods for health and nursing research as the base of their formation, both in their graduation and in their master's degree. Additionally, based on the general syllabus of this discipline, some challenges were clear, such as discussing the use of quantitative methods in the science of health and nursing; describing the quantitative research designs; and reading, interpreting and evaluating scientific research studies with quantitative approaches ${ }^{(10)}$.

Considering these challenges, the students expressed some concerns, such as: How would quantitative studies applicable to health and nursing sciences be understood? How efficient would teaching-learning methodologies be in aiding the construction of knowledge in quantitative researches? How should post-graduation students take on the role of protagonists in this educational process? Was the active teaching methodology "mock panels"the most coherent one to teach the necessary contents? Would that effectively enable reaching some of the learning objectives of the discipline?
These doubts were dissipated as the mock panels contributed to the formation of nursing doctors, which enabled students to assume the role of protagonists in the teaching-learning process through critical thinking and student autonomy, as systematically shown in Figure 1.

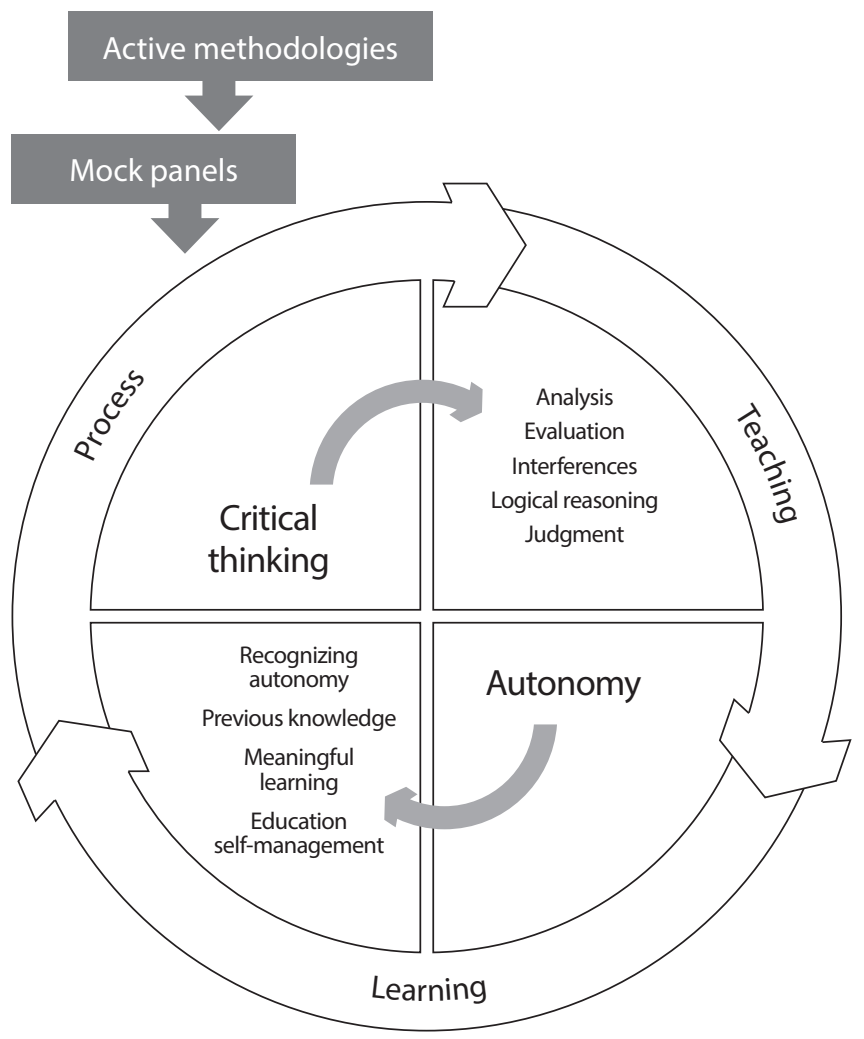

Figure 1 - Contributions of the active methodology "mock panels" for the formation of Nursing doctors, Universidade Federal do Rio Grande do Norte, Natal, Rio Grande do Norte, Brazil, 2019

In general, critical thinking is seen as a competence that should be acquired and improved during the process of formation of Nursing students. This favors the elaboration of arguments to understand phenomena beyond what is obvious, unveiling potentials and shortcomings of an object under study ${ }^{(11)}$.

This type of thought has been applied in many fields of knowledge, such as psychology, philosophy, education, and nursing. In the latter, it has been widely applied in clinical teaching, since it relates to the capacity to develop cognitive abilities such as analyzing, questioning, evaluating, conceptualizing, and understanding problems in a logic and adequate manner.

Similarly, in academic activities, learning permeated by critical thinking has an influential impact in the formation of professors that contribute for scientific advances in nursing ${ }^{(12)}$. That is because, with regards to its structural components, critical thought makes one think of elements such as reliability, contextual perspective, creativity, flexibility, curiosity, intellectual completeness, intuition, comprehension, and reflection. These components converge for the practice of cognitive behaviors, such as the application of standards, logical thinking, prediction, inferences, discerning, interpretation, and power of judgment. 
These cognitive skills are aspects required for the nurse, in the condition of professor-researcher, to have an optimal performance in circumstances in which they take on the role of evaluators of studies to be published in scientific journals, become members of panels to examine monographs or master's or doctor's degree researches, in addition to participating as members in commissions for academic selection processes.

These issues show that teaching demands recognizing the autonomy of the students and mutual respect between them and their professors, since there are no professors without students. Therefore, the differences are not simply that one is the object of the other ${ }^{(2)}$. Thus, teaching practices must be targeted at creating possibilities through which students can construct knowledge ${ }^{(14)}$.

That is only possible if the student is engaged in the learning process. This is the ideal condition to broaden their possibilities of exercising freedom and autonomy in decision making in many educational and social contexts, enabling them to prepare for the exercise of the profession in the future ${ }^{(15)}$.

The student, after all, has life experiences, previous knowledge and cultural practices, all of which can be the starting point for a significant learning process ${ }^{(2)}$. Teaching approaches that follow this line of thought, such as active methodologies, exemplified here through the use of mock panels, enable students to get involved with the activities proposed, and to self-manage their education ${ }^{(2)}$.

\section{FINAL CONSIDERATIONS}

In its use of the active teaching methodology of mock panels, the discipline showed that it is possible to rethink nursing education beyond the standards of expository classes and ad hoc evaluations for the students. Additionally, the students who participated in this discipline found that this strategy goes against the flow of traditional education models, since there were pedagogical disruptions that overcame the barriers of the mere transmission of information or content memorization.

The implementation of mock panels could be perceived as an innovative practice in the formation of Nursing doctors, since it showed itself as an opportunity of promoting critical thought and developing the autonomy of students in researches with quantitative approaches.

Said aspects showed how to overcome some issues that are historically problematic in the formation of nurses, such as the lack of motivation of students in evaluative activities; the lack of creativity in the execution of the tasks proposed; and the lack of motivation to be present in classes.

Counter to these challenges, this teaching practice led students to commit to the discipline, its professors, and evaluative activities; to effectively participate in classes; to develop analytical reasoning; to critically analyze different types of quantitative studies; and to develop the oratory capabilities in the examination of theses presented in the mock panels.-

This socialized experience is expected to raise the interest of other post-graduation programs, and even of Nursing graduation courses, which require end of course papers. However, it stands out that this active teaching methodology should not be taken as a standardized proposal for any educational setting. It is, still, a pedagogical strategy that can be re-modeled, respecting the specificities of different pedagogical contexts, including disciplines that deal not only with quantitative approaches, but with qualitative approaches as well.

\section{REFERENCES}

1. Scochi CGS, Munari DB, Gelbcke FL, Erdmann AL, Gutiérrez MGR, Rodrigues RAP. Pós-graduação Stricto Sensu em Enfermagem no Brasil: avanços e perspectivas. Rev Bras Enferm. 2013;66(esp):80-9. doi: org/10.1590/S0034-71672013000700011

2. Mitre SM, Siqueira-Batista R, Girardi-de-Mendonça JM, Morais-Pinto NM, Meirelles CAB, et al. Metodologias ativas de ensinoaprendizagem na formação profissional em saúde: debates atuais. Ciênc Saúde Coletiva. 2008;13(Suppl 2):2133-44. doi: 10.1590/ S1413-81232008000900018

3. Silva APSS, Pedro ENR. Autonomia no processo de construção do conhecimento de alunos de enfermagem: o chat educacional como ferramenta de ensino. Rev Latino-Am Enferm [Internet]. 2010 [cited 2019 Aug 5];18(2):[08 telas]. Available from: http://www.scielo.br/pdf/ rlae/v18n2/pt_11.pdf

4. Fonseca LMM, Aredes NDA, Fernandes AM, Batalha LMC, Apóstolo JMA, Martins JCA, et al. Computer and laboratory simulation in the teaching of neonatal nursing: innovation and impact on learning. Rev Latino-Am Enfermagem. 2016;24:e2808. doi: 10.1590/1518-8345.1005.2808.

5. Major CB, Arhur JP, Silva ÂTM, Mantovani MF, Felix JVC, Boostel R. Contribuições da simulação para estudantes de graduação em enfermagem. Rev Enferm UFPE. 2018;12(6):1751-62. doi: 10.5205/1981-8963-v12i6a230633p1751-1762-2018

6. Kim J, Park J, Shin S. Effectiveness of simulation-based nursing education depending on fidelity: a meta-analysis. BMC Med Educ. 2016;23(16). doi: 10.1186/s12909-016-0672-7.

7. Vargas CP, Diaz PS, Menegaz JC, Backes VMS, Kempfer SS, Lima DKS. Introdução da FlippedClassroom no ensino de enfermagem. Rev Enferm UFSM. 2018;8(4):829-40. doi: 10.5902/2179769226811

8. Costa RRO, Medeiros SM, Vitor AF, Lira ALBC, Martins JCA, Araújo MS. Tipos e finalidades da simulação no ensino de graduação em enfermagem: revisão integrativa da literatura. Rev Baiana Enferm. 2016;30(3). doi: 10.18471/rbe. v30i3.16589

9. Lima DVM. Desenho de pesquisa: uma construção para autores. O Bras J Nurs [Internet]. 2011 [cited 2019 Aug 5];10(2):1-14. Available from: http://www.objnursing.uff.br/index.php/nursing/article/ download/3648/pdf. 
10. Universidade Federal do Rio Grande do Norte (UFRN). Projeto Pedagógico e Regimento do Programa de Pós-Graduação Stricto Sensu em Enfermagem - Mestrado e Doutorado. Centro de Ciências da Saúde. Departamento de Enfermagem. Programa de Pós-graduação em Enfermagem. Curso de Mestrado e Doutorado. Natal, Rio Grande do Norte; 2010.

11. Riegel F, Crossetti MGO. Referenciais teóricos e instrumentos para avaliação do pensamento crítico na enfermagem e na educação. Rev Gaúcha Enferm [Internet]. 2018 [cited 2019 Aug 5]; 39:e2017-0097. Available from: https://seer.ufrgs.br/RevistaGauchadeEnfermagem/ article/view/ 79566/46554

12. Carbogim FC, Oliveira LB, Mendonça ET, Marques DA, Friedrich DBC, Püschel VAA. Ensino das habilidades do pensamento crítico por meio de "problem based learning". Texto Contexto Enferm. 2017;26(4):e1180017. doi: 10.1590/0104-07072017001180017

13. Bittencourt GKGD, Crossetti MGO. Critical thinking skills in the nursing diagnosis process. Rev Esc Enferm USP [Internet]. 2013 [cited 2019 Aug 5];47(2):341-7. Available from: http://www.scielo.br/pdf/reeusp/v47n2/10.pdf

14. Freire P. Pedagogia da autonomia: saberes necessários à prática educativa. 58a ed. São Paulo: Paz e Terra; 2019.

15. Berbel NAN. As metodologias ativas e a promoção da autonomia discente. Semina, Ciênc Soc Hum. 2011;32(1):25-40. doi: 10.5433/1679-0383 